\title{
PRELIMINARY RESULTS USING A NEW METHOD TO OPTIMIZE A SPRAY DRYER PROCESS FOR PRODUCING HIGH QUALITY MILK POWDER FROM COW, GOAT AND SHE-ASS MILK CONCENTRATES
}

\author{
Giuseppe Altieri, Giovanni Carlo Di Renzo, Francesco Genovese
}

\section{Introduction}

Spray dryers for milk powder production are commonly found in dairy plants, allowing a significant increase in heat and mass transfer with consequent reduction in drying time to a few seconds [17]. The products obtained, due to their extended shelf-life (up to two years) and nutritional properties, can be widely used in the food processing industry [22], for baking, ice-cream and chocolate manufacturing [2], reconstituting and so forth.

Since the typical composition of milk makes it very perishable, it must be transformed into a more stable product; among the various technologies available, spray drying has many advantages. Drying extends the shelf life of milk and at the same time reduces its weight and volume: this reduces the cost of transporting and storing the product. Moreover, due to cow milk intolerance and allergies $(1-3 \%$ of all infants) demand for replacement milk (such as goat milk, mare milk and she-ass milk) and related products is continually increasing [15]. In particular, sheass milk has valuable uses as a human feed, due to the similarity with human milk: this may allow its use for infant nourishment when cow milk and its related products can have side effects on a baby's health [3]. Nevertheless, for mares and she-asses milk production depends on calving seasonality. Hence variable productivity in terms of milk yield and quantity does not make it profitable to build industrial plants to bottle pasteurized raw milk or UHT or to produce soluble milk powder [9].

The main advantages of spray-drying are:

- feasibility of differing product properties, such as powder density and size; it is then possible to obtain a higher-quality product due to evaporative cooling of powder in the hot section and little time

Paper received 09.04.2008; accepted 20.10.2008

Università degli Studi della Basilicata, Facoltà di Agraria, Dipartimento DITEC, viale dell'Ateneo Lucano, 10, 85100 Potenza (Italy); phone: ++39-0971-205468, fax: ++39-0971-205429, e-mail: giuseppe.altieri@unibas.it contact, without overheating;

- spray-drying is recommended for thermo-sensitive products, such as pharmaceuticals, food products and chemicals, which can also require high vacuum processes and low temperature;

- low production costs and high productivity, low plant maintenance costs;

- safe technology, reduction in microbial risk; all the components are in contact with the product with hygienic processing standards;

- best thermal efficiency compared with other heat exchangers, as drum dryer or tunnel dryer.

The spray drying process requires milk heating, concentrating milk solids by evaporating up to $50 \%$ total solids and then concentrate spray drying to produce a powder. Proper processing ([4] [16] [20] [21]) parameters must protect nutritional, functional and sensorial properties. Indeed, high processing temperatures are known to favour the migration of lactose, protein and fat within the milk droplet and this has repercussions on the functional properties (particle size, density, solubility) of the milk powder ([10] [12] [13] [14]).

Heat damage measurement can be used to evaluate proper milk processing and assess powder quality by means of the Insolubility Index (II) and the Whey Protein Nitrogen Index (WPNI), expressed as milligrams of undenatured whey protein per gram of powder ([6] [7] [18] [20] [21]).

In this work the Authors define the project parameters of a small spray dryer plant for the production of soluble milk powder from goat and she-ass milk so as to adapt the seasonal production of these alternative milks to the constantly rising demand from the market; in addition cow milk was used as reference in the trials.

All classic quality indices (namely the insolubility index, thermal damage and protein denaturation) and vitamin $\mathrm{C}$ are used by the authors to evaluate proper milk processing. The correlation equations that result when the vitamin $C$ thermal degradation is compared with the thermal damage and with the insolubility index can be used to forecast the optimal spray dryer inlet air temperature that assures maximum quality re- 
quirements and spray dryer performance, in terms of optimized operative capacity and feed flow rate.

\section{Materials and methods}

A pressure nozzle laboratory co-current spray dryer (FT80-Armfield Limited), equipped with a peristaltic pump for feed fine control and cyclone collector of powder was used in this work. The spray tower was modified in our Lab to allow the internal flow to be axis-symmetric. This was accomplished through the use of an internal cylindrical diaphragm that shapes an axis-symmetric discharge duct: in this way both the evaporative capacity and the particle residence time were increased (see Fig. 1). In tab. 1 the FT80 spray dryer main operating parameter ranges are reported.

The trials were carried out on milk concentrates from cow, goat and she-ass milk so as to optimize the process performance of the spray dryer for each kind of milk, testing three inlet air temperatures $(120,150$, $\left.185^{\circ} \mathrm{C}\right)$, while keeping $\left(0.5 \mathrm{dm}^{3} / \mathrm{h}\right)$; outlet air RH\% was in the range $10-40 \%$, room air temperature was $25^{\circ} \mathrm{C}$ and $\mathrm{RH} \%$ about $40 \%$; raw milk samples were concentrated using a low pressure evaporator to an average $23 \%$ dry matter. Five repetitions for cow milk and three repetitions for goat and she-ass milk were
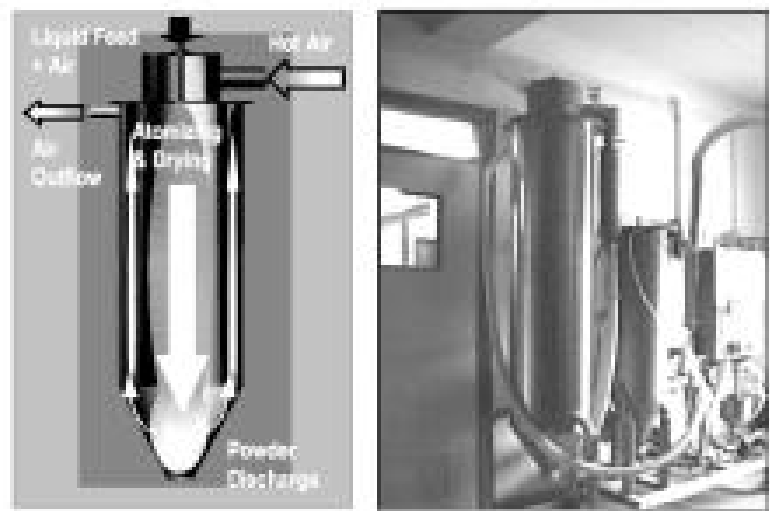

Fig. 1 - Modified FT80 spray dryer: (left) operating layout; (right) the Lab modified version of the FT80 spray dryer.

\begin{tabular}{|cc|}
\hline Parameter & $\begin{array}{c}\text { Range of } \\
\text { allowed } \\
\text { values }\end{array}$ \\
\hline Feed flow rate $(\mathrm{dm} 3 / \mathrm{h})$ & $0.2-7$ \\
Evaporated water $(\mathrm{dm} 3 / \mathrm{h})$ & $0.5-3$ \\
Air flow rate $(\mathrm{m} 3 / \mathrm{h})$ & $>60$ \\
Feed dry matter percent & $10-60$ \\
Hot air temperature $\left({ }^{\circ} \mathrm{C}\right)$ & $50-250$ \\
Nozzles $(\mathrm{n})$ & 1 \\
Mean residence time $(\mathrm{s})$ & $1-9$ \\
Allowed diameter of solid & $20-120$ \\
particles ( $\mu \mathrm{m})$ & \\
\hline
\end{tabular}

TABLE 1 - FT80 spray dryer main operating parameter ranges. carried out for each treatment. Each sample consisted of about 15 liters of raw milk. The main properties for each kind are reported in tab. 2.

The collected samples for each trial underwent physical and chemical analysis to measure the moisture content (UR\%), thermal damage (IDT), Insolubility (IINS), loss of vitamin $\mathrm{C}$, titratable acidity (OTA\%); during the trials the outlet discharge temperature (OT) and the $\mathrm{RH} \%$ of discharged air (ORH\%) were also recorded.

\begin{tabular}{|ccccc|}
\hline Milk $\begin{array}{c}\text { Fats } \\
(\mathrm{g} / 100 \mathrm{ml})\end{array}$ & $\begin{array}{c}\text { Proteins } \\
(\mathrm{g} / 100 \mathrm{ml})\end{array}$ & $\begin{array}{c}\text { Lactose } \\
(\mathrm{g} / 100 \mathrm{ml})\end{array}$ & $\begin{array}{c}\text { Conducti } \\
\text { vity } \\
(\mathrm{mS} / \mathrm{cm})\end{array}$ & $\begin{array}{c}\text { Dry } \\
\text { matter } \\
(\%)\end{array}$ \\
\hline cow $3.62(0.30)$ & $3.22(0.19)$ & $4.62(0.25)$ & 4.1 & 12.5 \\
$(0.08)$ & $(0.90)$ \\
goat $2.95(0.23)$ & $2.84(0.17)$ & $4.50(0.22)$ & 6.7 & 23.6 \\
& & $(0.13)$ & $(1.60)$ \\
she- & $0.57(0.05)$ & $1.75(0.10) 6.74(0.14)$ & 2.3 & 10.1 \\
ass & & $(0.02)$ & $(0.70)$ \\
\hline
\end{tabular}

TABLE 2 - Main chemical and physical properties of cow, goat and she-ass milk collected samples (mean values and standard deviation).

The moisture content was evaluated as the loss in weight (\%) after oven drying at $102^{\circ} \mathrm{C}$ until constant weight was reached.

The IDT was obtained through the assay of total soluble undenatured proteins compared to the total protein content (total nitrogen x 6.38); the levels of total nitrogen $(\mathrm{TN})$, soluble nitrogen $(\mathrm{SN})$ at $\mathrm{pH} 4.6$ and non-protein nitrogen (NPN) were determined via the Kjeldahl method, carrying all measurements in triplicate. The overall protein content was calculated as (TN-NPN) x 6.38. The ratio of insoluble protein at $\mathrm{pH} 4.6$ to the total amount of protein was calculated as (TN-SN)x100/TN, and was used to evaluate protein denaturation, as proposed by several authors [8].

The Insolubility Index (IINS) was obtained by measuring insoluble matter (as volume of sediments in $\mathrm{ml}$ ) after milk powder reconstitution in standard conditions and centrifugation for 10 minutes in a $1000 \mathrm{~g}$ centrifuge [11].

The vitamin $\mathrm{C}$ assay was conducted following the Official Methods of Analysis [1]; a small amount of vitamin $C$ (to a maximum of $5 \mathrm{mg} / \mathrm{l}$ ) was added to the raw milk samples where the vitamin $\mathrm{C}$ content was too low.

Titratable acidity is expressed as \% of lactic acid determined by titration of a known amount of reconstituted milk with $0.1 \mathrm{~N} \mathrm{NaOH}$, using phenolphthalein as indicator.

Statistical analysis [19] was carried out on each hypothetical correlation so as to obtain the best descriptive polynomial equation for each parameter: the degree of freedom (DOF) was first calculated, then the correlation coefficient $\left(\mathrm{R}^{2}\right)$ was corrected and once the confidence level was stated $(95 \%)$, the regression 
polynomial was calculated using Matlab $^{\mathrm{TM}}$ with a Least Squares method; finally the "root mean square error of correlation" (RMSEC) was evaluated for the obtained polynomial; moreover, with the stated confidence level, the symmetrical upper and lower confidence band error was measured, transformed into a correlation average relative percent error.

Moreover, after the statistical analysis of correlation, a statistical analysis of prediction was carried out to investigate how well the descriptive polynomial equation performs when applied to predictions for unknown samples [5]. The "leave-one-out cross-validation" method (LOOCV) was used obtaining a "root mean square error of prediction" (RMSEP). Then, with the stated confidence level, the symmetrical upper and lower confidence band error was measured, which was again transformed into a prediction average relative error percentage.

\section{Results and discussion}

Considering for the vitamin $\mathrm{C}$ a first-order destruction kinetic, from the measured concentration for concentrated milk and reconstituted milk powder, both referred to the dry matter content, the constant $(\mathrm{k})$ of the Arrhenius law and the energy of activation (Ea) were calculated, for each kind of milk powder and for any reference temperature. The decimal reduction time (D) of vitamin $\mathrm{C}$ for each kind of milk powder and for each inlet temperature of the spray dryer was then calculated (see tab. 3).

\begin{tabular}{|cccccc|}
\hline Milk & $\begin{array}{c}\text { E:al } \\
(\mathrm{kJJ} / \mathrm{mol})\end{array}$ & $\begin{array}{c}\mathrm{K}_{\text {ss }} \\
(\mathrm{l} / \mathrm{s})\end{array}$ & $\begin{array}{c}\mathrm{D}_{185} \\
(\mathrm{~s})\end{array}$ & $\begin{array}{c}\mathrm{D}_{150} \\
(\mathrm{~s})\end{array}$ & $\begin{array}{c}\mathrm{D}_{129} \\
(\mathrm{~s})\end{array}$ \\
\hline cow & 34.3 & 2.38 & 0.97 & 1.03 & 1.09 \\
gost & 34.2 & 2.18 & 1.06 & 1.12 & 1.19 \\
she-ass & 33.8 & 2.54 & 0.91 & 0.96 & 1.02 \\
\hline
\end{tabular}

TABLE 3 - Energy of activation (Ea), constant (k) and decimal reduction time (D), function of vitamin $\mathrm{C}$ decrease following a first order destruction kinetic (Arrhenius law), as measured from experimental data and for several spray dryer inlet temperatures.

In tab. 3 she-ass milk is shown to be very thermosensitive as can be seen from the Ea and $\mathrm{k}$ values because it has lower values for the decimal reduction time (D) while goat milk is the most resistant to thermal damage.

Statistical analysis in tab. 4 shows the $95 \%$ confidence level band for correlation and prediction as average relative percent error, related to the decimal reduction time of vitamin $\mathrm{C}$ versus inlet temperature for each kind of milk.

In tab. 5 the relation is shown between IINS and the inlet temperature of the spray dryer for each kind of milk. The IINS increases as the inlet temperature increases; moreover, goat and cow milk show the same IINS increase when the inlet temperature rises.
Statistical analysis shows that the second-degree polynomial of the inlet air temperature is the best to forecast the IINS.

Tab. 6 shows the relation between IDT and the inlet temperature of the spray dryer for each kind of milk; also the IDT curve increases as the inlet temperature increases and she-ass and cow milk have about the same IDT increase when the spray dryer inlet temperature rises. The statistical analysis shows that the second-degree polynomial of the inlet air temperature is the best to forecast IDT.

Moreover, as shown in tab. 5, tab. 6 and tab. 7, the correlation and prediction model of IDT and IINS vs. $\mathrm{D}$ could be a second-degree polynomial.

The prediction model of IINS vs. D (tab. 7) and the prediction model of IDT vs. D (tab. 8) shows the relation between the quality indices (IINS and IDT) and the decimal reduction time (D) of the vitamin $\mathrm{C}$ content: so it could be used to predict IINS and IDT values for each kind of milk and for a given reference temperature of inlet air in the spray dryer (see the correlation equations given in tab. 7 and tab. 8). Hence thus the time-consuming determination of IDT and IINS could be efficiently replaced by rapid determination of vitamin $\mathrm{C}$ content before and after heat treatment, this being related to IDT and IINS.

Simple calculations can be carried out to find the maximum allowable air inlet temperature, for each type of milk, to achieve an IINS $<1.25 \mathrm{ml}$ (the powder is "extra grade" (American Dry Milk Institute, ADMI)) and IDT $<80$ which denotes "weak" heat treatment; the equations involved in these calculations are summarised in tab. 9: they are the second order polynomial IINS(D), the second order polynomial IDT(D) and the first order polynomial $\mathrm{D}(\mathrm{T})$, $\mathrm{T}$ being the inlet air temperature in ${ }^{\circ} \mathrm{C}$.

The calculations to determine the maximum allowable inlet air temperature, for each type of milk, are reported in tab. 10: when applying the limits $\operatorname{IINS}(\mathrm{D})=1.20$ and IDT(D) $=80$ we obtain the maximum reduction time Dmax of the vitamin $\mathrm{C}$ that meets both the imposed limits. Hence from Dmax, solving equation $\mathrm{D}(\mathrm{T})$ for $\mathrm{T}$, we obtain the maximum allowable inlet air temperature Tmax.

In each of the three cases the value of Tmax may be observed to be limited by $\mathrm{IINS}=1.20 \mathrm{ml}$ : protein denaturation appears to play a secondary role in the limiting the process temperature; the lactose content of the concentrated milk sample is the primary limiting parameter for the maximum allowable inlet air temperature: a high lactose content corresponds to a low allowable process temperature as shown comparing the milk lactose content (tab. 2) with the predicted maximum inlet air temperature (tab. 11).

In tab. 11 the operating parameters of the spray dryer are reported for several kinds of milk, the concentrated mean dry matter percent being about $23 \%$.

In addition, tab. 11 shows the usual processing data of the small spray dryer and even the specific operating parameters for each type of milk such as inlet 
temperature, as found from the previous discussion and tab. 10; the feed flow rate is modified in agreement with the increasing or decreasing air inlet temperature, stated a value of $0.5 \mathrm{dm}^{3} / \mathrm{h}$ at $185^{\circ} \mathrm{C}$ of air inlet temperature of the spray dryer.

Spray dryer performance, in terms of evaporative capacity and feed flow rate are thus fully optimized for each type of milk used in order to obtain an "extra grade" milk powder.

Tab. 10 and tab. 11 show that the predicted maximum allowable inlet air temperature (both for cow and goat milk) lies outside the sampled process tem- perature interval, so this cannot be suitable for prediction purposes; however the predicted value of $187^{\circ} \mathrm{C}$ and $191^{\circ} \mathrm{C}$, with respect to the sampled interval from $120^{\circ} \mathrm{C}$ to $185^{\circ} \mathrm{C}$ (with a extent of $65^{\circ} \mathrm{C}$ ), is $(187$ $185) / 65=3.1 \%$ and $(191-185) / 65=9.2 \%$ respectively out of sampled temperature extent: this can be considered satisfactory for engineering purposes so the outside value is a reasonable predicted value even if it lies outside the sampled temperature range.

Finally in tab. 12 are reported the values of OTA\%: those values are uncorrelated with the process air temperature but depend uniquely from the raw milk freshness.

\begin{tabular}{|c|c|c|c|c|c|c|}
\hline & & & & & Correlation & Prediction \\
\hline Milk & $\begin{array}{c}\text { Equation } \\
\text { (first-degreo polynomial) } \\
\text { (T expressed in }{ }^{\circ} \mathrm{C} \text { ) }\end{array}$ & $\underset{\mathbf{R}^{2}}{\text { Adj }}$ & RMSEC & RMSEP & \multicolumn{2}{|c|}{ error band as average felative percent error } \\
\hline Cow & $1311911-0.001863 * T$ & 1.00 & 0.003295 & 0,003609 & $+/ .0 .69 \%$ & $+/=0.75 \%$ \\
\hline Goat & $1.428199-0.002019 * T$ & 1.00 & 0.001917 & 0.002259 & $+-0.41 \%$ & $+/-0.47 \%$ \\
\hline She-ass & $1222825-0.001717 * \mathrm{~T}$ & 1.00 & 0.002398 & 0.002882 & $+1-0.59 \%$ & $+j-0.69 \%$ \\
\hline
\end{tabular}

TABLE 4 - Statistical analysis carried out for the correlation equation of D vs. inlet temperature for each kind of milk: the table shows the $95 \%$ confidence level correlation and prediction average relative percent error.

\begin{tabular}{|c|c|c|c|c|c|c|}
\hline & & & & & Correlation & Prediction \\
\hline Milk & $\begin{array}{l}\text { Polynomial degree Equation of inlet } \\
\text { temperature T expressed in }{ }^{\circ} \mathrm{C}\end{array}$ & Adj. & RMSEC & RMSEP & emor band as avere & ge relative percent error \\
\hline \multirow{3}{*}{ Cow } & T & 0.94 & 0.061983 & 0.066755 & $+/ .18 .02 \%$ & $+i=19.27 \%$ \\
\hline & 2 & 0.99 & 0.019288 & 0.022 .322 & $+/ .5 .66 \%$ & $+\gamma-6.44 \%$ \\
\hline & 3 & 0.99 & 0,020149 & 0.023615 & $+3-5.97 \%$ & $+1-6.82 \%$ \\
\hline \multirow{3}{*}{ Goat } & 1 & 1.00 & 0.019288 & 0.022060 & $+\gamma-6.34 \%$ & $+1.7 .07 \%$ \\
\hline & 2 & 0.99 & 0.020044 & 0.026038 & $+i-6.82 \%$ & $+/-8.35 \%$ \\
\hline & 3 & 0.99 & 0.021973 & 0.030876 & $+1.7 .85 \%$ & $+4.9 .90 \%$ \\
\hline \multirow{3}{*}{ She-ass } & I & 0.89 & 0.045181 & 0.052591 & $+1-9.75 \%$ & $+1.11 .07 \%$ \\
\hline & 2 & 0.98 & 0.018944 & 0.624609 & $+1-4.23 \%$ & $+/ .5 .18 \%$ \\
\hline & 3 & 0.90 & 0.044419 & 0,032524 & $+1=10.42 \%$ & $+1.6,84 \%$ \\
\hline
\end{tabular}

TABLE 5 - Statistical analysis carried out for the correlation equation of IINS vs. inlet temperature for each kind of milk. The table shows the $95 \%$ confidence level correlation and prediction average relative percent error.

\begin{tabular}{|c|c|c|c|c|c|c|}
\hline & & & & & Correlation & Prediction \\
\hline Milk & $\begin{array}{l}\text { Polynomial degree Equation } \\
\text { of inlet temperature } \mathrm{T} \\
\text { expressed in }{ }^{\circ} \mathrm{C}\end{array}$ & $\begin{array}{l}\mathrm{Adj}^{2} \\
\mathrm{R}^{2}\end{array}$ & RMSEC & RMSEP & \multicolumn{2}{|c|}{ error band as average felative percent error } \\
\hline \multirow{3}{*}{ Cow } & 1 & 0,69 & 3,434880 & 3.702501 & $+1-12.55 \%$ & $+1-13.44 \%$ \\
\hline & 2 & 0.98 & 0.963848 & 1.115437 & $+-3.55 \%$ & $+i-4.05 \%$ \\
\hline & 3 & 0.97 & 1.012436 & 1.763040 & $+1-3.77 \%$ & $+/-6.40 \%$ \\
\hline \multirow{3}{*}{ Goat } & 1 & 1.00 & 0.887845 & 1.012655 & $+i=6.19 \%$ & $+1.6 .88 \%$ \\
\hline & 2 & 1.00 & 0.36 .3654 & 0.472401 & $+<2.62 \%$ & $+i-3.21 \%$ \\
\hline & 3 & 1.00 & 0.678997 & 0.726626 & $+i-5.15 \%$ & $+-4.94 \%$ \\
\hline \multirow{3}{*}{ She-ass } & 1 & 0.94 & 3.090539 & 3.527401 & $+/ .13 .46 \%$ & $+1.14 .98 \%$ \\
\hline & 2 & 1.00 & 0.603730 & 0.784268 & $+62.72 \%$ & $+i=3.33 \%$ \\
\hline & 3 & 0.99 & 0.906484 & 1.092242 & $+1-4.29 \%$ & $+/ .4 .64 \%$ \\
\hline
\end{tabular}

TABLE 6 - Statistical analysis carried out for the correlation equation of IDT vs. inlet temperature for each kind of milk, the table shows the $95 \%$ confidence level correlation and prediction average relative error percent. 


\begin{tabular}{|c|c|c|c|c|c|c|}
\hline & & & & & Correlation & Prediction \\
\hline Milk & $\begin{array}{l}\text { Equation of D } \\
\text { (scosand-degree polynomial) }\end{array}$ & $\begin{array}{l}\text { Adj, } \\
R^{2}\end{array}$ & RMSEC & RMSEP & error band as & ve percent error \\
\hline Cow & $\begin{array}{c}42.215879 \\
-75.744946^{\circ} \mathrm{D} \\
+34.430266^{*} \mathrm{D}^{2}\end{array}$ & 0.99 & 0.028128 & 0.032370 & $+1.8 .25 \%$ & $+1.9 .34 \%$ \\
\hline Goat & $\begin{array}{c}5.939534 \\
-4.190216 * D \\
-0.339208 * D^{2}\end{array}$ & 1.00 & 0.019844 & 0.026258 &,$+-6.75 \%$ & $+1.8 .42 \%$ \\
\hline $\begin{array}{l}\text { She- } \\
\text { ass }\end{array}$ & $\begin{array}{r}27.638347 \\
-52.602742 * \mathrm{D} \\
+25.957887 \cdot \mathrm{D}^{2} \\
\end{array}$ & 0.98 & 0.019329 & 0.024888 & $+i-4.32 \%$ & $+\sqrt{-5.24 \%}$ \\
\hline
\end{tabular}

TABLE 7 - Statistical analysis carried out for the correlation equation of IINS vs. D for each kind of milk. The table shows the 95\% confidence level correlation and prediction average relative percent error. The correlation and prediction model must be a second-degree polynomial of $\mathrm{D}$.

\begin{tabular}{|c|c|c|c|c|c|c|}
\hline & & & & & Correlation & Prediction \\
\hline Milk & $\begin{array}{c}\text { Equation of D } \\
\text { (second-desree polyoomial) }\end{array}$ & Adj- & RMSEC & RMSEP & \multicolumn{2}{|c|}{ error band as avenge relative percent error } \\
\hline Cow & $\begin{array}{c}2025.886777 \\
-3732.496242 * \mathrm{D} \\
+1766.278613 * \mathrm{D}^{2}\end{array}$ & 0.97 & 1.135953 & 1.342394 & $+3-4.19 \%$ & $+1.4 .87 \%$ \\
\hline Goat & $\begin{array}{c}977.663190 \\
-1385.725054 * \mathrm{D} \\
+489.093819 * \mathrm{D}^{2}\end{array}$ & 1.00 & 0.525200 & 0.686983 & $+1-3.79 \%$ & $+1-4.67 \%$ \\
\hline She-ass & $\begin{array}{c}2064,826751 \\
-3939.363645 * D \\
+1920.641752 * D^{2}\end{array}$ & 0.99 & 1.015627 & 1.331095 & $+1-4.58 \%$ & $+1.5 .65 \%$ \\
\hline
\end{tabular}

TABLE 8 - Statistical analysis carried out for the correlation equation of IDT vs. D for each kind of milk. The table shows the 95\% confidence level correlation and prediction average relative percent error. The correlation and prediction model must be a second-degree polynomial of D.

\begin{tabular}{|c|c|c|c|c|}
\hline & & & Correlation & Prediction \\
\hline Milk & Parameter & $\begin{array}{l}\text { Polynomial Equation of correlation and prediction } \\
\text { model (inles air temperature T expressed in }{ }^{\circ} \mathrm{C} \text { ) }\end{array}$ & \multicolumn{2}{|c|}{$\begin{array}{c}\text { error band as averige relative percent } \\
\text { error }\end{array}$} \\
\hline \multirow[b]{2}{*}{ Cow } & IINS(D) & $42.2159 \cdot 75.7449 * \mathrm{D}+34.4303 * \mathrm{D}^{2}$ & $+/-8.25 \%$ & $+1-9.34 \%$ \\
\hline & $\begin{array}{l}\text { WT(D) } \\
\text { D(T) }\end{array}$ & $\begin{array}{c}2025.8868-3732.4962 * \mathrm{D}+1766.2786 * \mathrm{D}^{2} \\
1.3119-0.001863 * \mathrm{~T}\end{array}$ & $\begin{array}{r}+\%-4.19 \% \\
+1-0.69 \% \\
\end{array}$ & $\begin{array}{l}+-4.87 \% \\
+1-0.75 \% \\
\end{array}$ \\
\hline \multirow[b]{2}{*}{ Goat } & IINS(D) & $5.9395 \cdot 4.1902 * \mathrm{D}-0.3392 * \mathrm{D}^{2}$ & $+1-6.75 \%$ & $+1-8.42 \%$ \\
\hline & $\begin{array}{l}\operatorname{IDT}(\mathrm{D}) \\
\text { D(T) }\end{array}$ & $\begin{array}{c}977.6632-1385.7251 * \mathrm{D}+489.0938 * \mathrm{D}^{2} \\
1.4282-0.002019 * \mathrm{~T}\end{array}$ & $\begin{array}{l}4 /-3.79 \% \\
+\%-0.41 \% \\
\end{array}$ & $\begin{array}{l}+i-4.67 \% \\
+i-0.47 \%\end{array}$ \\
\hline \multirow[b]{2}{*}{ She-ass } & IINS(D) & $27.6383-52.6027 \cdot \mathrm{D}+25.9579 \cdot \mathrm{D}^{2}$ & $+1.4 .32 \%$ & $+i-5.24 \%$ \\
\hline & $\begin{array}{l}\text { IDT(D) } \\
\text { D(T) }\end{array}$ & $\begin{array}{c}2064.8268-3939.3636 * \mathrm{D}+1920.6418 * \mathrm{D}^{2} \\
1.2228-0.001717 * \mathrm{~T}\end{array}$ & $\begin{array}{l}+1.4 .58 \% \\
+3.0 .59 \%\end{array}$ & $\begin{array}{l}+i-5.65 \% \\
+i-0.69 \%\end{array}$ \\
\hline
\end{tabular}

TABLE 9 - Correlation and prediction model polynomial equations related to tab. 4, tab. 7 and tab. 8 for the IINS and IDT vs. the decimal reduction time of the vitamin C content (D) and for D vs. the spray dryer inlet air temperature (T) in ${ }^{\circ} \mathrm{C}$, for each type of milk powder.

\section{Conclusion}

The trials carried out on the spray dryer allowed assessment of heat treatment on matter other than classical cow milk. A chemical marker for powder quality was set up, namely vitamin C: the vitamin C degradation rate was measured (both $\mathrm{k}$ and $\mathrm{Ea}$ of the Arrhenius law was calculated) and correlated with the inlet spray dryer temperature, index of insolubility and index of thermal damage.

As expected, milk powder thermal damage increased with the inlet air temperature; the outlet powder $\mathrm{RH} \%$ was $96-98 \%$ very weakly correlated with the mass flow rate on the concentrate inlet. Moreover, the destruction kinetic of vitamin $\mathrm{C}$ was found correlated with both thermal damage and the insolubility of 


\begin{tabular}{|c|c|c|c|c|}
\hline Milk & Parameter & $\begin{array}{l}\text { Polynomial equation of correlation and prediction } \\
\text { model (inlet air temperature } T \text { expressed in }{ }^{\circ} \mathrm{C} \text { ) }\end{array}$ & $\begin{array}{l}\mathrm{D} \text { and maximum } \\
\mathrm{D} \text { to determine } \\
\text { Tmax }\end{array}$ & $\begin{array}{c}\text { Maximum } \\
\text { allowable inlet ait } \\
\text { temperature Tmax } \\
\text { in }{ }^{\circ} \mathrm{C}\end{array}$ \\
\hline & IINS(D) $=1.20$ & $42.2159-75.7449 * \mathrm{D}+34.4303 * \mathrm{D}^{2}$ & 0.96 & \\
\hline Cow & $\begin{array}{l}\text { IDT(D) }-80 \\
\text { D(T) } \\
\text { [INS(D) }-1.20\end{array}$ & $\begin{array}{c}2025.8868-3732.4962 * \mathrm{D}+1766.2786 * \mathrm{D}^{2} \\
1.3119-0.001863 * \mathrm{~T} \\
5.9395 \cdot 4.1902+\mathrm{D}-0.3392+\mathrm{D}^{2}\end{array}$ & $\begin{array}{c}0.94 \\
\max (D)=0.96 \\
{[.04}\end{array}$ & $187.1=($ IDT $=69.4)$ \\
\hline Gout & $\begin{array}{l}\text { IDT(D) }=80 \\
\text { DIT }\end{array}$ & $\begin{array}{c}977.6632-1385.7251 * \mathrm{D}+489.0938 * \mathrm{D}^{2} \\
1.4282-0.002019 * \mathrm{~T}\end{array}$ & $\begin{array}{c}1.00 \\
\max (D)=1.04\end{array}$ & $190,8 *($ IDT $-64,4)$ \\
\hline She-ass & $\begin{array}{l}\text { IINS(D) }=1.20 \\
\text { IDT(D) }-80 \\
\text { D(T) }\end{array}$ & $\begin{array}{c}27.6383-52.6027 * \mathrm{D}+25.9579 * \mathrm{D}^{2} \\
2064.8268-3939.3636 * \mathrm{D}+1920.6418 * \mathrm{D}^{2} \\
1.2228-0.001717 * \mathrm{~T}\end{array}$ & $\begin{array}{l}0.92 \\
0.89 \\
\max (D)-0.92\end{array}$ & $174.6(\mathrm{IDT}-65.0)$ \\
\hline
\end{tabular}

* This predicted value lies outside the sampled interval snd must be taken into account as the forecast value outside the range of the model's prediction. It may or may not be suitable for prediction purposes, and statistical analysis can carry out no confidence estimate of it.

TABLE 10 - Correlation and prediction model polynomial equations applied to predict the maximum allowable spray dryer air inlet temperature (Tmax) in ${ }^{\circ} \mathrm{C}$, for each type of milk powder, to respect the requirements of IINS $<1.25 \mathrm{ml}$ and IDT<80; the values of Tmax are limited by IINS $=1.20 \mathrm{ml}$ and are thus in agreement with the lactose content of raw milk samples as reported in tab. 2.

\begin{tabular}{|c|c|c|}
\hline Milk & Parameter & Value \\
\hline \multirow{4}{*}{ Usual processing data } & process air flow rate $\left(\mathrm{n}^{3} /\right)$ & 30 \\
\hline & room temperature $\left({ }^{\circ} \mathrm{C}\right)$ & 25 \\
\hline & room $\mathrm{RH} \%$ & 40 \\
\hline & average concentrate dry matter percent & 23 \\
\hline \multirow{2}{*}{ Cow } & inlet air temperature $\left({ }^{\circ} \mathrm{C}\right)$ & $187^{\circ}$ \\
\hline & concentrate feed flow rate $\left(\mathrm{dm}^{2} / \mathrm{h}\right)$ & 0.51 \\
\hline \multirow{2}{*}{ Goat } & inlet air temperature $\left({ }^{\circ} \mathrm{C}\right)$ & $191^{*}$ \\
\hline & concentrate feed flow rate $\left(\mathrm{dm}^{3} / \mathrm{h}\right)$ & 0.52 \\
\hline \multirow{2}{*}{ She-ass } & inlet air temperarure $\left({ }^{\circ} \mathrm{C}\right)$ & 175 \\
\hline & concentrate feed flow nate $\left(\mathrm{dm}^{3} / \mathrm{h}\right)$ & 0.47 \\
\hline
\end{tabular}

- This predicted value lies outside the sampled incerval and must be taken into account as the forecass value outside the range of the model's prediction. It may or may not be suitable for prediction purposes, and statistical analysis can carry out no confidence estimate of it.

TABLE 11 - Operating parameters of the spray dryer for each type of milk as derived from trials and earlier correlations.

\begin{tabular}{|ccc|}
\hline Milk & Inlet air tempernture ${ }^{\circ} \mathrm{C}$ & OTA\% \\
\hline \multirow{3}{*}{ Cow } & 120 & 0.14 \\
& 150 & 0.15 \\
& 185 & 0.14 \\
\hline \multirow{3}{*}{ Gosat } & 120 & 0.13 \\
& 150 & 0.14 \\
& 185 & 0.11 \\
\hline \multirow{3}{*}{ She-ass } & 120 & 0.07 \\
& 150 & 0.05 \\
& 185 & 0.05 \\
\hline
\end{tabular}

TABLE 12 - OTA\% values for each type of reconstituted milk powder vs. inlet air temperature (mean values).

the milk powder.

By using the calculated correlation equations the value of IINS and IDT can be predicted for each type of milk and spray dryer inlet temperature. Hence the time-consuming determination of IDT and IINS can be replaced by the quick determination of the vitamin $\mathrm{C}$ content before and after heat treatment.

She-ass milk was very sensitive to heat treatment because it has lower decimal reduction times (D) while goat milk is the most resistant to thermal damage.

At $175^{\circ} \mathrm{C}$ inlet air temperature the overall thermal treatment on the she-ass milk concentrate, which is very heat sensitive due to its high lactose content, was "weak" (IDT<80) and the milk powder of "premium or extra" quality (IINS $<1.25 \mathrm{ml}$ and lactic acid = $0.07 \%<0.15 \%$, ADMI).

The titratable acidity values are uncorrelated with the process air temperature but depend uniquely from the raw milk freshness.

Further investigations are required to study the interdependency between the quality of the drying matter and thermodynamics of the drying process. This holds particularly for the spray dryer which up to now has operated mainly as a result of individual expertise.

From preliminary results it would seem possible to build a small farm plant that allows pasteurization, concentration and powdering of milk from she-asses and goats, which is inexpensive and offers very good results in terms of the quality of the achieved powder products. 


\section{References}

[1] AOAC., Official Methods of Analysis (17 th ed.). (2002), Washington, DC, Association of Official Analytical Chemists.

[2] Attaie H., Breitschun B., BRAun P., Windhab E.J., The functionality of milk powder and its relationship to chocolate mass processing, in particular the effect of milk powder manufacturing and composition on the physical properties of chocolate masses. International Journal of Food Science and Technology (2003), (38), 3, 325-335

[3] Belli Blanes R., Il latte d'asina a confronto con il latte materno, il caprino, il bovino e le formule commerciali. Atti del Convegno - L'asino: attualità e prospettive dell'impiego in campo medico, zootecnico ed alimentare. Mondello, (2001) 25 May: 59-68.

[4] Birchal V.S., Passos M.L., Wildhagen G.R.S., MuJUMDAR A.S., The influence of spray dryer operation variables on milk powder quality. Drying 2004 - Proceedings of the $14^{\text {th }}$ International Drying Symposium (IDS 2004), Sao Paulo, Brazil, 22-25 August 2004, (A), 389-396.

[5] Cocchi D., RagGi M., Cross-Validation methods in regression problems. XLI Riunione Scientifica della Società Italiana di Statistica, Milan (Italy), 5-7 June 2002, Ed. CLEUP Padova, 117-120.

[6] Daeman A.L.H., van DeR STege H.J., The destruction of enzymes and bacteria during the spray-drying of milk and whey, 2: the effect of the drying conditions. Netherlands Milk and Dairy Journal (1982), (3), 36: 211-229.

[7] DE RITTER E., Stability characteristics of vitamins in processed food. Food Technology (1976), (30), 1: 43-54.

[8] De Wit J.N., Klarenbeek G., Hontelez-BackX E., Evaluation and functional properties of whey protein concentrates and whey protein isolates. 1. isolation and characterization, Netherlands Milk and Dairy Journal (1983), (37): 37-49.

[9] DOREAU M., BOULOT S., Recent knowledge on mare milk production: a review. Livestock Production Science (1989), (22): 213-235.

[10] Havea P., Protein interactions in milk protein concentrate powders. International Dairy Journal (2006), (16): 415-422.

[11] IDF standard 129A. Dried milk and dried milk products: Determination of insolubility index. (1988). International Dairy Federation, Brussels.

[12] Indyk H., LitTlejohn V., Woollard D.C., Stability of vitamin D3 during spray drying of milk. Food chemistry (1995), (57): 283-286.

[13] NiJdam J.J., LANGRISH T.A.G., The effect of surface composition on the functional properties of milk powders. Journal of Food Engineering (2006), (77): 919 925.

[14] OldField D.J., TAYlor M.W., SingH H., Effect of preheating and other process parameters on whey protein reactions during skim milk powder manufacture. International Dairy Journal (2005), (15): 501-511.

[15] Peelto L., Laitinen I., Matti L.E., Current perspectives on milk hypersensitivity. Food Science and Technology (1999), (10): 229-233.

[16] PÈREZ-CORREA J.R., FARİAS F., Modelling and control of a spray dryer: a simulation study. Food Control (1995), (6), 4: 219-227.
[17] Piatkowski M., ZBICINSKI I., Analysis of the mechanism of counter-current spray drying. Transp. Porous Med. (2007), (66): 89-101.

[18] PìsECKY J., Spray drying in the cheese industry. International Dairy Journal (2005), (15): 531-536.

[19] Snedecor G.W., Coochran W.G., Statistical Methods. Eight Edition (1989), Iowa State University Press, Ames, Iowa 50010.

[20] Straatsma J., Van Houwelingen G., Steenbergen A.E., DE Jong P., Spray drying of food products: 1 . Simulation model. Journal of Food Engineering (1999), (42): 67-72.

[21] Straatsma J., Van Houwelingen G., Steenbergen A.E., De Jong P., Spray drying of food products: 2. Prediction of insolubility index. Journal of Food Engineering (1999), (42): 73-77.

[22] Uysal H., Kilic S., Kavas G., Akbulut N., KeSENKAS H., Some properties of set yoghurt made from caprine milk and bovine-caprine milk mixtures fortified by ultrafiltration or the addition of skim milk powder. International Journal of Dairy Technology (2003), (56), 3: 177-181.

\section{SUMMARY}

As quality is a very important factor in milk powder produced by drying, the optimal process must protect both nutritional and sensorial properties. Although heat damage indices (namely the insolubility index (IINS), thermal damage (IDT), protein denaturation) could be used to evaluate the correct processing of milk, they are very time-consuming. Hence a chemical marker, like vitamin $\mathrm{C}$, is proposed for rapid assessment of the overall damage to the quality of the produced milk powder.

Trials were carried out on milk concentrates from cow, goat and she-ass so as to optimize the process performance of the spray dryer, for each kind of milk, at three inlet temperatures $\left(120,150,185{ }^{\circ} \mathrm{C}\right)$; the feed flow rate was set at $0.5 \mathrm{dm}^{3} / \mathrm{h}$ with outlet air RH\% in the range 10-40\%; raw milk was concentrated using a low pressure evaporator until an average level of $23 \%$ dry matter was reached.

As expected, the thermal damage of the milk powder increased as the inlet air temperature increased; the outlet powder $\mathrm{RH} \%$ was $96-98 \%$ poorly correlated with the mass flow rate of the concentrate inlet. Moreover, the destruction kinetic of vitamin $\mathrm{C}$ was found highly correlated with the thermal damage to the milk powder. At $175{ }^{\circ} \mathrm{C}$ inlet air temperature the overall thermal treatment on the she-ass milk concentrate, which is very heat-sensitive due to its high lactose content, was "weak" (IDT<80) and the milk powder of "premium or extra" quality (IINS $<1.25 \mathrm{ml}$ and lactic acid $=0.07 \%<0.15 \%$ ADMI). The titratable acidity values are uncorrelated with the process air temperature but depend uniquely from the raw milk freshness.

\section{Key words:}

spray drying, dairy industry, milk powder, thermal damage index. 
005_DiRenzo(532)_35 18-02-2009 15:46 Pagina 42 